\title{
Effectiveness of trivalent seasonal influenza vaccine in preventing laboratory-confirmed influenza in primary care in the United Kingdom: 2012/13 end of season results
}

N Andrews (Nick.Andrews@phe.gov.uk) ${ }^{1}$, J McMenamin², H Durnall ${ }^{3}$, J Ellis4, A Lackenby4 ${ }^{4}$, C Robertson²,5,6, B von Wissmann², S Cottrell, B Smyth ${ }^{8}$, C Moore $^{7}$, R Gunson', M Zambon', D Fleming ${ }^{3}$, R Pebody $^{1}$

1. Public Health England Health Protection Directorate, Colindale, London, United Kingdom

2. Health Protection Scotland, Glasgow, United Kingdom

3. Royal College of General Practitioners Research and Surveillance Centre, Birmingham, United Kingdom

4. Public Health England Operations Directorate, Microbiology Services, Colindale, London, United Kingdom

5. University of Strathclyde, Glasgow, United Kingdom

6. International Prevention Research Institute, Lyon, France

7. Public Health Wales, Cardiff, United Kingdom

8. Public Health Agency Northern Ireland, Belfast, United Kingdom

9. West of Scotland Specialist Virology Centre, Glasgow, United Kingdom

Citation style for this article:

Andrews N, McMenamin J, Durnall H, Ellis J, Lackenby A, Robertson C, von Wissmann B, Cottrell S, Smyth B, Moore C, Gunson R, Zambon M, Fleming D, Pebody R. Effectiveness of trivalent seasonal influenza vaccine in preventing laboratory-confirmed influenza in primary care in the United Kingdom: $2012 / 13$ end of season results. Euro Surveill. 2014;19(27):pii=20851. Available online: http://www.eurosurveillance.org/ViewArticle.aspx?Articleld=20851

Article submitted on 25 September 2013 / published on 10 July 2014

The effectiveness of the $2012 / 13$ trivalent seasonal influenza vaccine (TIV) was assessed using a testnegative case-control study of patients consulting primary care with influenza-like illness in the United Kingdom. Strain characterisation was undertaken on selected isolates. Vaccine effectiveness (VE) against confirmed influenza $A\left(\mathrm{H}_{3} \mathrm{~N}_{2}\right), A\left(\mathrm{H}_{1} \mathrm{~N}_{1}\right)$ and $B$ virus infection, adjusted for age, sex, surveillance scheme (i.e. setting) and month of sample collection was $26 \%$ (95\% confidence interval $(\mathrm{Cl}):-4$ to 48$), 73 \%$ (95\% Cl: 37 to 89 ) and $51 \%(95 \% \mathrm{Cl}: 34$ to 63 ) respectively. There was an indication, although not significant, that VE declined by time since vaccination for influenza $\mathrm{A}\left(\mathrm{H}_{3} \mathrm{~N}_{2}\right)$ (VE $50 \%$ within three months, $2 \%$ after three months, $p=0.25)$. For influenza $A\left(\mathrm{H}_{3} \mathrm{~N}_{2}\right)$ this is the second season of low VE, contributing to the World Health Organization (WHO) recommendation that the 2013/14 influenza vaccine strain composition be changed to an $\mathrm{A}\left(\mathrm{H}_{3} \mathrm{~N}_{2}\right)$ virus antigenically like cell-propagated prototype 2012/13 vaccine strain (A/Victoria/361/2011). The lower VE seen for type $B$ is consistent with antigenic drift away from the 2012/13 vaccine strain. The majority of influenza B viruses analysed belong to the genetic clade 2 and were antigenically distinguishable from the $2012 / 13$ vaccine virus $B /$ Wisconsin/1/2010 clade 3. These findings supported the change to the WHO recommended influenza $B$ vaccine component for 2013/14.

\section{Introduction}

The 2012/13 influenza season in the United Kingdom (UK) was unusually long with elevated levels of activity persisting from week 50 to 16. In England, Northern Ireland and Wales, the season was dominated initially by circulation of influenza B virus, with school outbreaks in the period before Christmas. This was followed by influenza $\mathrm{A}\left(\mathrm{H}_{3} \mathrm{~N}_{2}\right)$ virus circulation particularly in the New Year and spring with influenza outbreaks in often highly vaccinated care home populations [1]. Scotland presented a different picture with influenza activity initially dominated by influenza $\mathrm{A}\left(\mathrm{H}_{3} \mathrm{~N}_{2}\right)$ followed by influenza $B$ virus circulation.

The occurrence of late season influenza A outbreaks in much of the UK some months after the completion of the $2012 / 13$ influenza vaccine campaign led to questions being raised about waning intra-seasonal vaccine protection. A similar observation of late season influenza $A\left(\mathrm{H}_{3} \mathrm{~N}_{2}\right)$ outbreaks in care home settings in $2011 / 12$ was accompanied by the observation of significant intra-seasonal waning in protection for those vaccinated more than three months previously [2]. Trivalent seasonal influenza vaccine (TIV) in 2012/13 included an $\mathrm{A} /$ California/7/2009 ( $\left.\mathrm{H}_{1} \mathrm{~N}_{1}\right)$ pdmog-like virus, an $A /$ Victoria/361/2011 ( $\left.\mathrm{H}_{3} \mathrm{~N}_{2}\right)$-like virus and a $\mathrm{B} /$ Wisconsin/1/2010-like virus (Yamagata lineage). In $2012 / 13$, vaccine uptake was $73.4 \%$ in those aged over 65 years and $51.3 \%$ in risk groups with individuals aged under 65 years in England [1].

Mid-season estimates from the UK and elsewhere were published in January 2013 with vaccine effectiveness (VE) against all influenza types ranging from $45 \%$ in Canada to $50 \%$ in a European study and $51 \%$ in the UK 
Reference influenza B haemagglutinin 1 sequences used in phylogenetic analysis

\begin{tabular}{|c|c|c|c|c|c|c|c|}
\hline Virus isolate & Segment & $\begin{array}{l}\text { Sequence } \\
\text { source }\end{array}$ & $\begin{array}{c}\text { Segment ID/ } \\
\text { Accession number }\end{array}$ & Country & $\begin{array}{l}\text { Collection date } \\
\text { (year-month- } \\
\text { day) }\end{array}$ & $\begin{array}{l}\text { Originating } \\
\text { laboratory }\end{array}$ & $\begin{array}{l}\text { Submitting } \\
\text { laboratory }\end{array}$ \\
\hline B/Wisconsin/01/2010 & $\mathrm{HA}$ & $\begin{array}{l}\text { GISAID } \\
\text { EpiFlu }\end{array}$ & $\mathrm{EPI} 271600$ & $\begin{array}{l}\text { United } \\
\text { States }\end{array}$ & $2010-02-20$ & $\begin{array}{c}\text { Wisconsin State } \\
\text { Laboratory of } \\
\text { Hygiene }\end{array}$ & $\begin{array}{l}\text { Centers for Disease } \\
\text { Control and } \\
\text { Prevention }\end{array}$ \\
\hline B/Estonia/55669/2011 & $\mathrm{HA}$ & $\begin{array}{l}\text { GISAID } \\
\text { EpiFlu }\end{array}$ & EPI319345 & Estonia & 2011-03-14 & $\begin{array}{l}\text { Health Protection } \\
\text { Inspectorate Estonia }\end{array}$ & $\begin{array}{l}\text { National Institute } \\
\text { for Medical } \\
\text { Research }\end{array}$ \\
\hline $\mathrm{B} /$ Odessa/3886/2010 & $\mathrm{HA}$ & $\begin{array}{l}\text { GISAID } \\
\text { EpiFlu }\end{array}$ & $\mathrm{EPI} 271913$ & Ukraine & 2010-03-19 & $\begin{array}{l}\text { Ministry of Health of } \\
\text { Ukraine }\end{array}$ & $\begin{array}{l}\text { National Institute } \\
\text { for Medical } \\
\text { Research } \\
\end{array}$ \\
\hline B/Florida/4/o6 & $\mathrm{HA}$ & GenBank & CYo73895 & $\mathrm{N} / \mathrm{A}$ & $\mathrm{N} / \mathrm{A}$ & $\mathrm{N} / \mathrm{A}$ & $\mathrm{N} / \mathrm{A}$ \\
\hline B/HongKong/330/2001 & $\mathrm{HA}$ & GenBank & AJ783379 & $\mathrm{N} / \mathrm{A}$ & $\mathrm{N} / \mathrm{A}$ & $\mathrm{N} / \mathrm{A}$ & $\mathrm{N} / \mathrm{A}$ \\
\hline B/Victoria/2/87 & $\mathrm{HA}$ & GenBank & CY018757 & $\mathrm{N} / \mathrm{A}$ & $\mathrm{N} / \mathrm{A}$ & $\mathrm{N} / \mathrm{A}$ & $\mathrm{N} / \mathrm{A}$ \\
\hline B/Yamagata/16/88 & $\mathrm{HA}$ & GenBank & CYo18765 & $\mathrm{N} / \mathrm{A}$ & $\mathrm{N} / \mathrm{A}$ & $\mathrm{N} / \mathrm{A}$ & N/A \\
\hline B/Malaysia/2506/2004 & $\mathrm{HA}$ & GenBank & $\mathrm{YO}_{3} 8287$ & $\mathrm{~N} / \mathrm{A}$ & $\mathrm{N} / \mathrm{A}$ & $\mathrm{N} / \mathrm{A}$ & $\mathrm{N} / \mathrm{A}$ \\
\hline B/Victoria/304/2006 & $\mathrm{HA}$ & GenBank & $\mathrm{EU}_{124261}$ & $\mathrm{~N} / \mathrm{A}$ & $\mathrm{N} / \mathrm{A}$ & $\mathrm{N} / \mathrm{A}$ & $\mathrm{N} / \mathrm{A}$ \\
\hline B/Brisbane/60/2008 & $\mathrm{HA}$ & GenBank & FJ766840 & $\mathrm{N} / \mathrm{A}$ & $\mathrm{N} / \mathrm{A}$ & $\mathrm{N} / \mathrm{A}$ & $\mathrm{N} / \mathrm{A}$ \\
\hline
\end{tabular}

ID: identity; GISAID: Global Initiative on Sharing Avian Influenza Data; HA: haemagglutinin; N/A: not applicable.

[3-5]. This study presents the end-of-season VE for the 2012/13 seasonal TIV in preventing medically attended confirmed influenza $A\left(\mathrm{H}_{3} \mathrm{~N}_{2}\right), A\left(\mathrm{H}_{1} \mathrm{~N}_{1}\right)$ pdmog and $B$ virus infection using the established primary care sentinel swabbing surveillance schemes in the UK $[2,3,6]$. It also examines the protective effect of vaccination measured at different points during the season and by time since vaccination, to determine if there is any evidence of intra-seasonal waning protection.

\section{Methods}

\section{Study population and period}

Data were derived from five primary care influenza sentinel swabbing surveillance schemes in the UK from England (two schemes), Northern Ireland, Scotland, and Wales. Details of the Royal College of General Practitioners (RCGP), Public Health England (PHE) Specialist Microbiology Network (SMN), Public Health Agency (PHA) of Northern Ireland, Health Protection Scotland (HPS) and Public Health Wales swabbing schemes have been published previously [7].

The study period ran from 1 October 2012 to 24 April 2013. Patients were swabbed as part of clinical care, with verbal consent. Cases were defined, as persons presenting during the study period in a participating general practitioner (GP) practice with an acute influenza-like illness (ILI) who were swabbed and then tested positive for influenza A or B. ILI was defined as an individual presenting in primary care with an acute respiratory illness with physician-diagnosed fever or complaint of feverishness. Controls were individuals presenting with ILI in the same period who were swabbed and tested negative for influenza.
A standardised questionnaire was completed by the GP responsible for the patient during the consultation. Demographic, clinical and epidemiological information was collected from cases and controls, including date of birth, sex, defined underlying clinical risk group, date of onset of respiratory illness, date of specimen collection, and influenza vaccination status for the 2012/13 season with vaccination dates.

\section{Laboratory methods}

Laboratory confirmation was undertaken using realtime polymerase chain reaction (RT-PCR) assays capable of detecting circulating influenza $A$ viruses, influenza $B$ viruses and other respiratory viruses $[8,9]$. Samples in England were sent to the PHE Microbiology Services, Colindale (RCGP scheme) or one of the specialist PHE microbiology laboratories (SMN scheme). Samples in Northern Ireland were sent to the Regional Virus Laboratory, Belfast, in Scotland to the West of Scotland Specialist Virology Centre, Glasgow (HPS scheme), and in Wales to the Public Health Wales Specialist Virology Centre, Cardiff.

Further strain characterisation was also performed. Influenza viruses were isolated in Madin-Darby canine kidney (MDCK) or MDCK-SIAT1 cells from all RT-PCR positive samples from England as previously described [10]. Virus isolates with a haemagglutination titre $\geq 40$ were then characterised antigenically using post-infection ferret antisera in haemagglutination inhibition $(\mathrm{HI})$ assays, with guinea pig $\left(\mathrm{A}_{3}\left(\mathrm{H}_{3} \mathrm{~N}_{2}\right)\right.$ viruses $)$ or turkey $\left(A_{(}\left(\mathrm{H}_{1} \mathrm{~N}_{1}\right)\right.$ pdmog and influenza $B$ viruses) red blood cells [11]. Nucleotide sequencing of the HA1 region of the haemagglutinin (HA) gene of a subset of influenza $B$ viruses was performed (primer sequences available on request), and phylogenetic trees were constructed with a neighbour-joining algorithm available in the 
Swabbing results in the United Kingdom, week 402012 to week $162013^{\text {a }}$ ( $\mathrm{n}=4,649$ individuals)

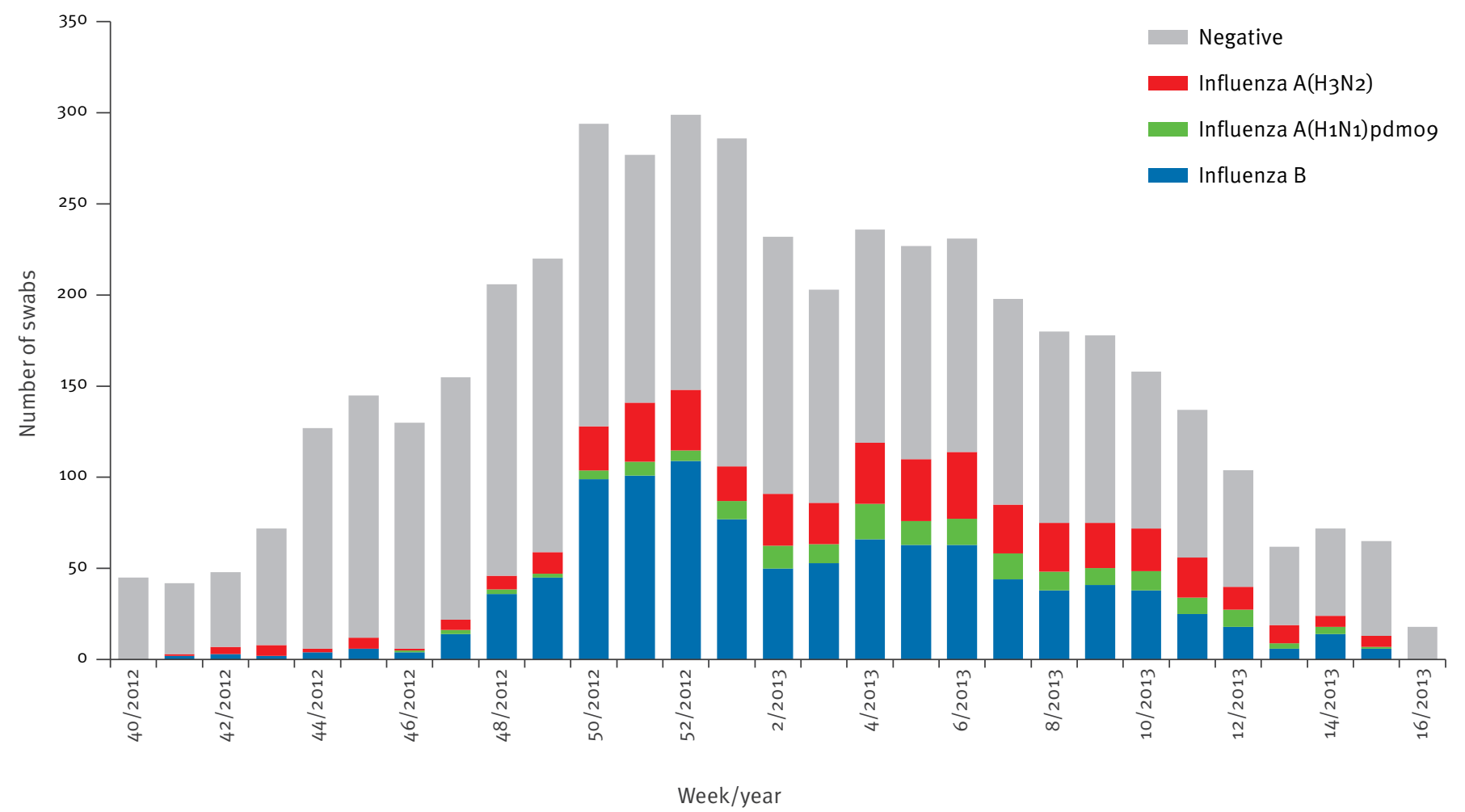

a Corresponding to the period from 1 October 2012 to 24 April 2013.

Mega 4.0.1 software (http://www.megasoftware.net). Influenza B samples were selected for sequencing to be representative of the range of patient's age, date of sample collection, geographical location, and antigenic characterisation of the influenza $B$ virus isolate, if performed. HA sequences from reference strains used in the phylogenetic analysis were obtained from the National Center for Biotechnology Information (NCBI) GenBank and EpiFlu database of the Global Initiative on Sharing Avian Influenza Data (GISAID) (Table 1).

\section{Statistical methods}

Persons were defined as vaccinated if the date of vaccination with the 2012/13 TIV was 14 or more days before onset of illness. Those in whom the period between vaccination and onset of illness was less than 14 days were excluded from analysis. If the date of vaccination was missing, as the $2012 / 13$ campaign occurred before influenza circulation was common, it was assumed that TIV vaccination was more than 14 days before onset date. Those with a missing date of onset or an onset date more than seven days before the swab was taken were excluded.

VE was estimated by the test-negative case-control (TNCC) design [12]. In this design VE is calculated as 1 (odds ratio) obtained using multivariable logistic regression models with influenza A or influenza B PCR results as outcomes and seasonal vaccination status as the linear predictor. Influenza A results were also further categorised for $\mathrm{A}\left(\mathrm{H}_{3} \mathrm{~N}_{2}\right)$ and $\mathrm{A}\left(\mathrm{H}_{1} \mathrm{~N}_{1}\right)$ pdmog viruses. In the analyses evaluating VE for a specific type or strain, those positive for other types were excluded. Age (coded into five standard age groups, $<5,5-14,15-44$, 45-64 and 065 years), sex, clinical risk group, surveillance scheme (RCGP, SMN, PHA of Northern Ireland, HPS, Public Health Wales) and date of sample collection (month) were investigated as potential confounding variables. To investigate whether the VE changed in relation to time since vaccination analyses stratifying VE by time since vaccination ( $<3$ months - i.e. 91 days,$- \geq 3$ months) and by period (October to January, February to April) were undertaken. Where date of vaccination was not given, time since vaccination was estimated based on assuming vaccination occurred at the median vaccination date of 20 October 2012, and also treated as missing in a sensitivity analysis. To test for the significance of changes in VE with time since vaccination, the multivariable logistic regression was performed in vaccinated individuals with days since vaccination (between vaccination and symptom onset date) included as a continuous variable and with the binary variable of $<3$ months and $\geq 3$ months since vaccination. VE was also assessed stratified by age and scheme with differences in VE tested by a likelihood ratio test between groups where numbers were not too low for a precise estimate. All statistical analyses were carried out in Stata version 12 (StataCorp, College Station, Texas). 


\section{FIGURE 2}

Monthly influenza positivity rates by country, United Kingdom, 2012/13 influenza season ( $\mathrm{n}=4,649$ individuals)

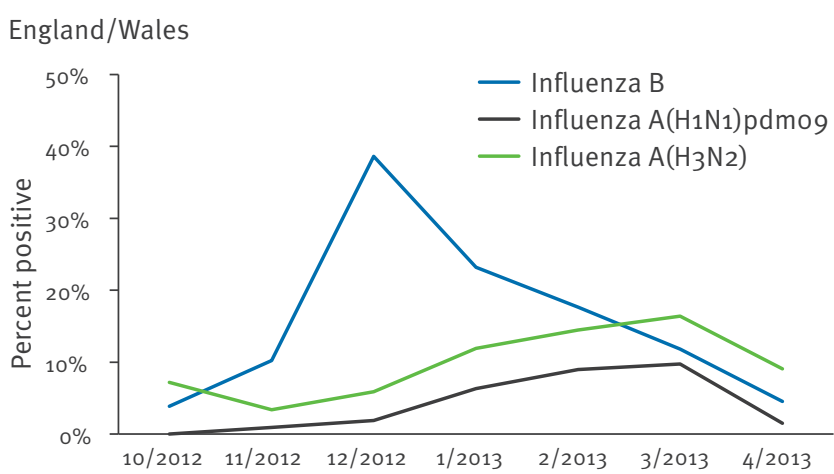

Northern Ireland
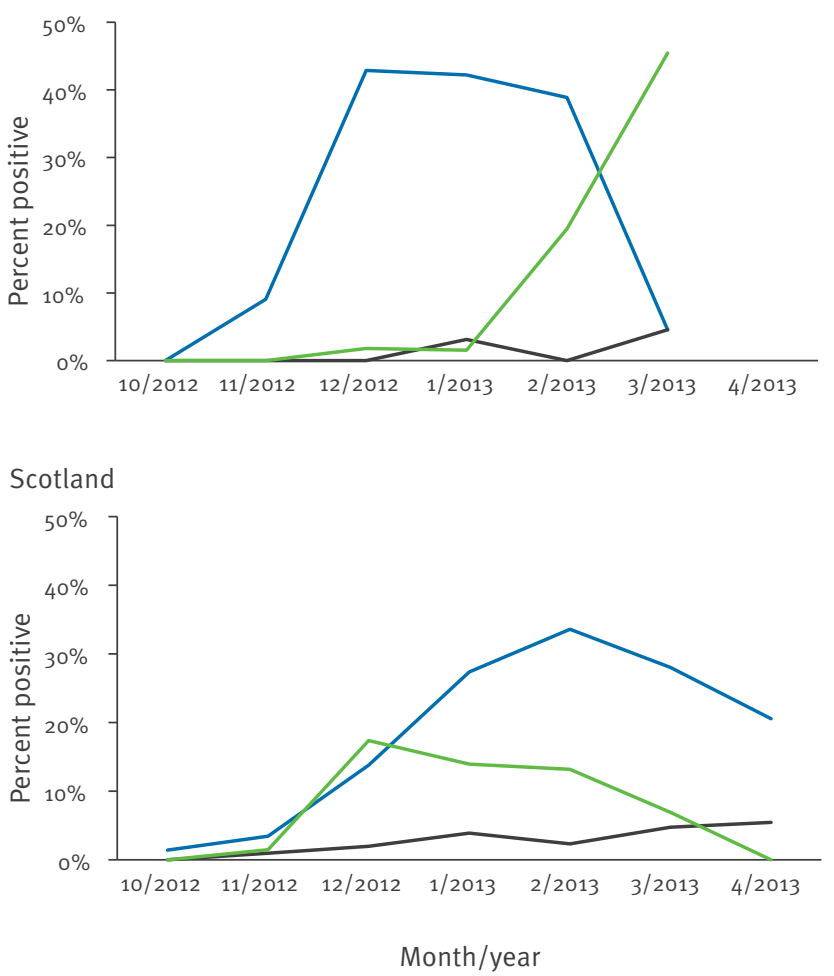

\section{Results}

A total of 4,649 individuals were swabbed in primary care during the study period and had a laboratory result available. Figure 1 shows the numbers of swabs and swab results over the study period and Figure 2 shows positivity rates for England/Wales, Northern Ireland and Scotland during 2012/13, indicating the different timing of influenza $A$ and $B$ virus circulation in Scotland to the rest of the UK. For the VE analysis two individuals were excluded due to an inconclusive result, 350 due to a missing symptom onset date, 839 because they were swabbed more than seven days after symptom onset, 143 due to missing vaccination status and 29 because they were vaccinated within 14 days of onset. The details of the 3,286 individuals remaining in the study are given in Table 2 according to the swab result. Positivity rates differed significantly by all variables in this table.

\section{Strain characterisation}

Antigenic analysis by $\mathrm{HI}$ assay of influenza $\mathrm{A}\left(\mathrm{H}_{3} \mathrm{~N}_{2}\right)$ viruses isolated from positive samples submitted through the RCGP scheme, demonstrated that these viruses were antigenically homogeneous, and closely related antigenically (<fourfold differences in $\mathrm{HI}$ assays for all 89 tested) to the cell-propagated $\mathrm{H}_{3} \mathrm{~N}_{2}$ vaccine strain, A/Victoria/361/2011 [1]. The relatively fewer influenza $A\left(\mathrm{H}_{1} \mathrm{~N}_{1}\right)$ pdmog viruses isolated in 2012/13 were closely related antigenically to the $A\left(\mathrm{H}_{1} \mathrm{~N}_{1}\right)$ pdmog 2012/13 vaccine strain, A/California/7/2009, though six of thirty isolates did show reduced reactivity in antigenic characterisation assays with antiserum raised against influenza $A / C a l i f o r n i a / 7 / 2009$ (>fourfold difference in $\mathrm{HI}$ assays).

Of the 2012/13 UK influenza B viruses analysed, the majority $(411 / 482,85 \%)$ were characterised as belonging to the $B /$ Yamagata/16/88-lineage, as was the $2012 / 13$ influenza $B$ vaccine strain, $B /$ Wisconsin/1/2010 (Figure 3). Genetically, the HA genes of B-Yamagata 2012/13 strains fell within two HA genetic clades (clade 2 and 3). The majority of influenza B UK viruses analysed belonged to genetic clade 2 (Figure 3), and were antigenically distinguishable from the $2012 / 13$ vaccine virus, B/Wisconsin/1/2010 clade 3. Of the 193 $\mathrm{B} /$ Yamagata-lineage viruses analysed antigenically, only $20(10.3 \%)$ were antigenically similar to the B/ Wisconsin/1/2010 vaccine component. The majority showed reduced reactivity in antigenic characterisation assays with antiserum raised against influenza B/Wisconsin/1/2010, with 65 (33.7\%) showing a fourfold difference and 108 (56.0\%) a greater than fourfold difference.

\section{Model fitting for vaccine effectiveness estimation} When estimating vaccine effects, age group, sex, time period (defined by month of sample collection) and surveillance scheme were adjusted for in a multivariable logistic regression model. Although all these variables, except sex, were significantly associated with having a positive swab, only age group was a confounder for the vaccine effects (changed the estimate by more than $5 \%$ ). Information on risk group was missing for 182 of 3,286 samples $(5.5 \%)$ and was therefore not included in the final model. If risk group was included, it was found not to be associated with being positive and the VE estimates remained similar.

Tables 3 and 4 show VE estimates against influenza $A\left(\mathrm{H}_{3} \mathrm{~N}_{2}\right), A\left(\mathrm{H}_{1} \mathrm{~N}_{1}\right)$ pdmog and $B$ according to vaccination status and time since vaccination and period.

\section{Vaccine effectiveness against influenza $\mathrm{A}$}

infection

The adjusted VE of TIV against influenza A was $35 \%$ (95\% confidence interval (CI): 11 to 53 ), however this 
differed for influenza $A\left(\mathrm{H}_{3} \mathrm{~N}_{2}\right)$ and $\mathrm{A}\left(\mathrm{H}_{1} \mathrm{~N}_{1}\right)$ pdmo9. For influenza $\mathrm{A}\left(\mathrm{H}_{1} \mathrm{~N}_{1}\right)$ pdmog overall VE was $73 \%(95 \% \mathrm{Cl}$ : 37 to 89 ) compared to $26 \%$ ( $95 \% \mathrm{Cl}:-4$ to 48 ) for influenza $\mathrm{A}\left(\mathrm{H}_{3} \mathrm{~N}_{2}\right)$.

For influenza $A\left(\mathrm{H}_{1} \mathrm{~N}_{1}\right)$ pdmo9, VE showed evidence of a decline by time since vaccination (Table 4). For influenza $\mathrm{A}\left(\mathrm{H}_{3} \mathrm{~N}_{2}\right)$, there was also evidence of a decline in VE from $50 \%(95 \% \mathrm{Cl}: 16$ to 71$)$ within three months of vaccination to $2 \%(95 \% \mathrm{Cl}:-49$ to 36$)$ after three months. This decline was not, however statistically significant $(p=0.25)$ and was less apparent when looking at VE by period (Table 3). Assessing time since vaccination with those with a missing date of vaccination excluded gave similar results with a decline from $100 \%(95 \% \mathrm{Cl}: 56$ to 100$)$ to $63 \%(95 \% \mathrm{Cl}:-7$ to 87$)$ for influenza $A\left(\mathrm{H}_{1} \mathrm{~N}_{1}\right)$ pdmog and from $41 \%(95 \% \mathrm{Cl}: 0$ to 66$)$ to $5 \%(95 \% \mathrm{Cl}$ : -51 to 41$)$ for influenza $A\left(\mathrm{H}_{3} \mathrm{~N}_{2}\right)$.

The adjusted age-specific estimate for influenza $A$ protection was lower in the oldest age group ( $\geq 65$ years compared to other ages) (Table 4), however, the observed differences were not significant. VE in the vaccine target group (aged $\geq 65$ years or in a risk group) was $13 \%$ ( $95 \% \mathrm{Cl}:-44$ to 67$)$ due to the low VE estimate in those aged $\geq 65$ years. VE also showed some

\section{TABLE 2}

Details for influenza A and B cases and controls, United Kingdom, October 2012-April 2013 (n=3,286 individuals)

\begin{tabular}{|c|c|c|c|c|c|c|}
\hline & $\begin{array}{l}\text { Total cases and } \\
\text { controls }^{\mathrm{a}}\end{array}$ & $\begin{array}{c}\text { Controls } \\
(\mathrm{N}=1,956) \\
\mathrm{n}(\%)\end{array}$ & $\begin{array}{c}\text { Influenza B } \\
\text { cases }(\mathrm{N}=827)^{\mathrm{b}} \\
\mathrm{n}(\%)\end{array}$ & $\begin{array}{c}\text { Influenza A } \\
\text { cases }(N=506)^{b} \\
n(\%)\end{array}$ & $\begin{array}{c}\mathrm{A}\left(\mathrm{H}_{1} \mathrm{~N}_{1}\right) \text { pdmog } \\
\text { cases }(\mathrm{N}=127) \\
\mathrm{n}(\%)\end{array}$ & $\begin{array}{c}\mathrm{A}\left(\mathrm{H}_{3} \mathrm{~N}_{2}\right) \text { cases } \\
(\mathrm{N}=354) \\
n(\%)\end{array}$ \\
\hline \multicolumn{7}{|l|}{ Age group (years) } \\
\hline$<5$ & 294 & $214(72.8)$ & $50(17.0)$ & $31(10.5)$ & $10(3.4)$ & $19(6.5)$ \\
\hline 5-14 & 406 & $185(45.6)$ & $172(42.4)$ & 49 (12.1) & $10(2.5)$ & $35(8.6)$ \\
\hline $15-44$ & 1,485 & $884(59.5)$ & $341(23.0)$ & $261(17.6)$ & $74(5.0)$ & 176 (11.9) \\
\hline $45-64$ & 822 & $471(57.3)$ & $229(27.9)$ & $123(15.0)$ & $31(3.8)$ & $85(10.3)$ \\
\hline$\geq 65$ & 268 & $196(73.1)$ & $32(11.9)$ & $40(14.9)$ & $1(0.4)$ & $38(14.2)$ \\
\hline Missing & 11 & $6(54.5)$ & $3(27.3)$ & $2(18.2)$ & $1(9.1)$ & $1(9.1)$ \\
\hline \multicolumn{7}{|l|}{ Sex } \\
\hline Male & 1,321 & $748(56.6)$ & $355(26.9)$ & $219(16.6)$ & $50(3.8)$ & 157 (11.9) \\
\hline Female & 1,919 & $1,179(61.4)$ & $463(24.1)$ & $279(14 \cdot 5)$ & $72(3.8)$ & $194(10.1)$ \\
\hline Missing & 46 & $29(63.0)$ & $9(19.6)$ & $8(17.4)$ & $5(10.9)$ & $3(6.5)$ \\
\hline \multicolumn{7}{|l|}{ Surveillance scheme } \\
\hline RCGP & 1,535 & $920(59.9)$ & $397(25.9)$ & $219(14 \cdot 3)$ & $72(4.7)$ & $147(9.6)$ \\
\hline SMN & 408 & $274(67.2)$ & $69(16.9)$ & $65(15.9)$ & $16(3.9)$ & $30(7.4)$ \\
\hline HPS & 1,086 & $653(60.1)$ & $265(24.4)$ & $170(15.7)$ & $32(2.9)$ & $132(12.2)$ \\
\hline Public Health Wales & 87 & $31(35.6)$ & $39(44.8)$ & $17(19.5)$ & $3(3.4)$ & $14(16.1)$ \\
\hline PHA of Northern Ireland & 170 & $78(45.9)$ & $57(33.5)$ & $35(20.6)$ & $4(2.4)$ & $31(18.2)$ \\
\hline \multicolumn{7}{|l|}{ Risk group } \\
\hline No & 2,488 & $1,432(57.6)$ & $669(26.9)$ & $388(15.6)$ & $108(4.3)$ & $261(10.5)$ \\
\hline Yes & 616 & $419(68.0)$ & $115(18.7)$ & $84(13.6)$ & $9(1.5)$ & $70(11.4)$ \\
\hline Missing & 182 & $105(57.7)$ & $43(23.6)$ & $34(18.7)$ & $10(5.5)$ & $23(12.6)$ \\
\hline \multicolumn{7}{|c|}{ Interval symptom onset-sample (days) } \\
\hline $0-1$ & 442 & $279(63.1)$ & $79(17.9)$ & $84(19.0)$ & $20(4.5)$ & $59(13.3)$ \\
\hline $2-4$ & 1,810 & $1,016(56.1)$ & $496(27.4)$ & $299(16.5)$ & $79(4.4)$ & $205(11.3)$ \\
\hline $5-7$ & 1,034 & $661(63.9)$ & $252(24.4)$ & $123(11.9)$ & $28(2.7)$ & $90(8.7)$ \\
\hline \multicolumn{7}{|l|}{ Vaccination status } \\
\hline Unvaccinated & 2,752 & $1,577(57.3)$ & $747(27.1)$ & $431(15.7)$ & $120(4.4)$ & $291(10.6)$ \\
\hline Vaccinated (14-91 days agoc) & 292 & $226(77.4)$ & $43(14.7)$ & $23(7.9)$ & $0(0.0)$ & $20(6.8)$ \\
\hline Vaccinated (>91 days agoc) & 242 & $153(63.2)$ & $37(15.3)$ & $52(21.5)$ & $7(2.9)$ & $43(17.8)$ \\
\hline
\end{tabular}

HPS: Health Protection Scotland; PHA: Public Health Agency; RCGP: Royal College of General Practitioners' surveillance Scheme; SMN: PHE Specialist Microbiology Network.

Numbers and row percentages (to indicate positivity ratesa) are shown. For example of those 294 swabbed aged $<5$ years, $72.8 \%$ were negative, $17.0 \%$ had influenza B and $10.5 \%$ had influenza $A$.

Differences between cases and controls for all variables in this table were statistically significant, chi-squared test.

a Two individuals positive for influenza $A\left(\mathrm{H}_{3} \mathrm{~N}_{2}\right)$ and $\mathrm{B}$ and one individual positive for $\mathrm{A}\left(\mathrm{H}_{1} \mathrm{~N}_{1}\right)$ pdmog and $\mathrm{B}$, are included in both the influenza $B$ and influenza A columns. For the totals in this column, these individuals are only counted once.

25 influenza A cases were of unknown strain, these are included in influenza A VE analysis but not the strain specific analyses. Also two individuals positive for influenza $A\left(\mathrm{H}_{3} \mathrm{~N}_{2}\right)$ and $B$ and one individual positive for $A\left(\mathrm{H}_{1} \mathrm{~N}_{1}\right)$ pdmog and $B$ are included in both the influenza $B$ and influenza A columns, which is why the total adds to 3,289 for controls, influenza A and influenza B.

Where a date of vaccination was missing $(n=150)$ this was estimated by assuming vaccination was on 20 October 2012 , the median time of vaccination in controls with onset in 2013. 


\section{FIGURE 3}

Phylogenetic analysis with sequences from reference viruses downloaded from NCBI GenBank and GISAID EpiFlu databases of influenza B sequences derived from patients in the United Kingdom, 2012/13 influenza season

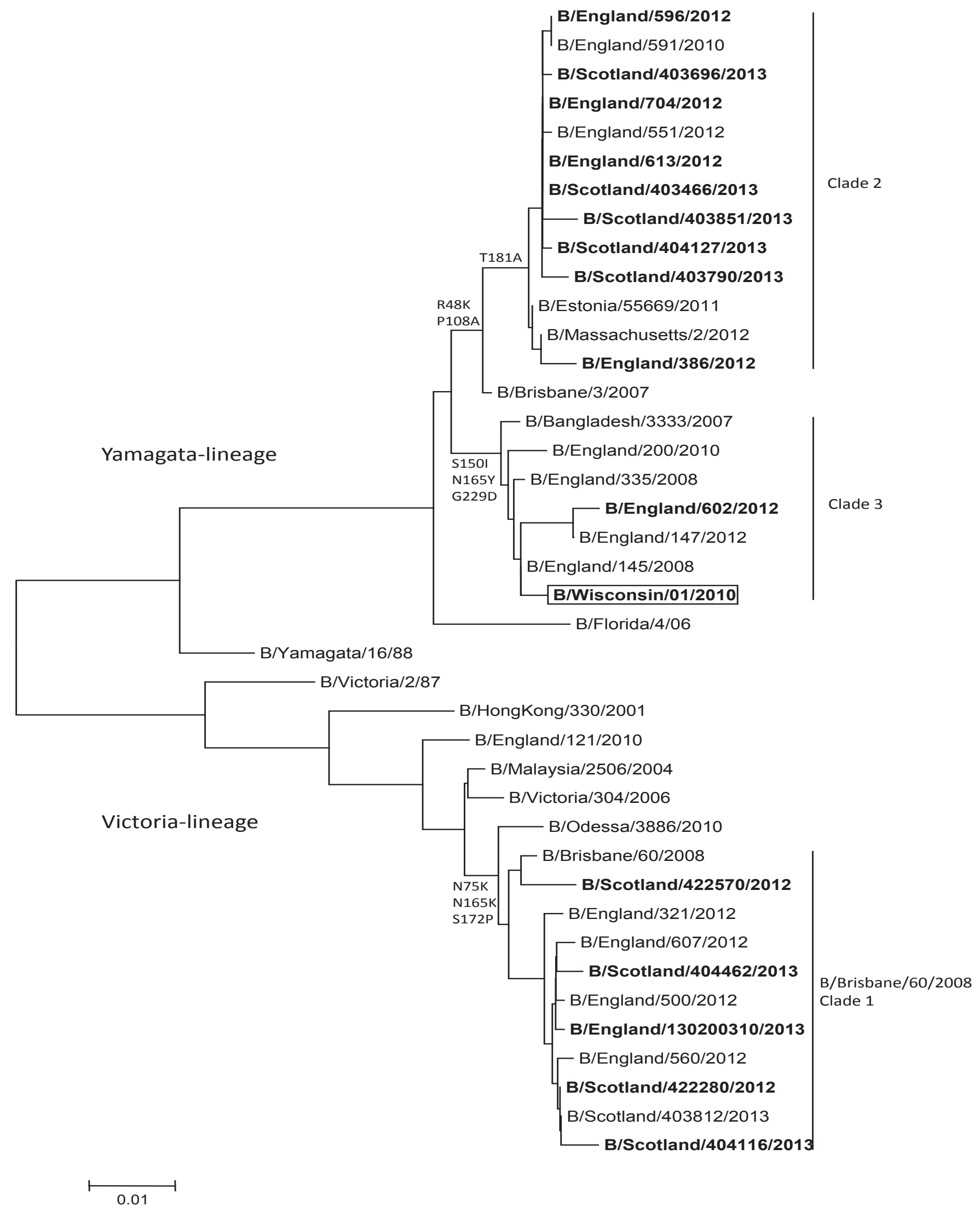

GISAID: Global Initiative on Sharing Avian Influenza Data; NCBI: National Center for Biotechnology Information. 


\section{TABLE 3}

Adjusted vaccine effectiveness estimates based on samples positive (cases, $\mathrm{N}=1,330$ ) and negative (controls, $\mathrm{N}=1,956)$ for influenza according to vaccination status, United Kingdom, October 2012-April 2013

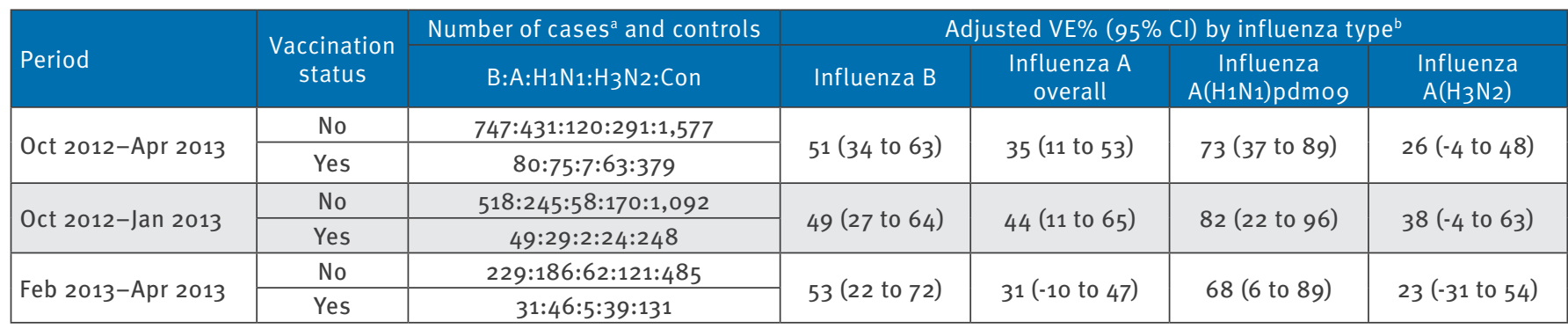

A: influenza A; B: influenza B; $\mathrm{Cl}$ : confidence interval; con: control; $\mathrm{H}_{1} \mathrm{~N}_{1}$ : influenza $\mathrm{A}\left(\mathrm{H}_{1} \mathrm{~N}_{1}\right)$ pdmo9; $\mathrm{H}_{3} \mathrm{~N}_{2}$ : influenza $\mathrm{A}\left(\mathrm{H}_{3} \mathrm{~N}_{2}\right)$; VE: vaccine effectiveness.

a Because two individuals positive for influenza $A\left(\mathrm{H}_{3} \mathrm{~N}_{2}\right)$ and $B$, and one individual positive for $A\left(\mathrm{H}_{1} \mathrm{~N}_{1}\right)$ pdmog and $B$ are included in both the influenza B and influenza A cases, summing up the cases presented in this column amounts to 1,333 instead of 1,330.

b Adjusted for age group, sex, month of sample collection and surveillance scheme.

\section{TABLE 4}

Adjusted vaccine effectiveness estimates for influenza by age, surveillance scheme and by time since vaccination, United Kingdom, October 2012-April 2013

\begin{tabular}{|c|c|c|c|c|}
\hline \multirow{2}{*}{ Factor } & \multicolumn{4}{|c|}{ Adjusted VE $\%$ (95\% CI) by influenza type } \\
\hline & Influenza B & Influenza A overall & Influenza $\mathrm{A}\left(\mathrm{H}_{1} \mathrm{~N}_{1}\right)$ pdmog & Influenza $\mathrm{A}\left(\mathrm{H}_{3} \mathrm{~N}_{2}\right)$ \\
\hline \multicolumn{5}{|l|}{ Age (in years) } \\
\hline$\langle 5$ & n too low ${ }^{b}$ & n too low & $\mathrm{n}$ too low $^{\mathrm{b}}$ & $\mathrm{n}$ too low $^{\mathrm{b}}$ \\
\hline $5-14$ & 74 (1 to 93) & $\mathrm{n}$ too low ${ }^{\mathrm{b}}$ & $\mathrm{n}$ too low ${ }^{\mathrm{b}}$ & $\mathrm{n}$ too low $^{\mathrm{b}}$ \\
\hline $15-44$ & $68(46$ to 82$)$ & $54(21$ to 73$)$ & $83(28$ to 96$)$ & $40(-7$ to 66$)$ \\
\hline $45-64$ & $34(-1$ to 57$)$ & $37(-10$ to 63$)$ & $90(20$ to 99$)$ & $32(-27$ to 63$)$ \\
\hline All $<65$ & $50(32$ to 63$)$ & $43(19$ to 61$)$ & $76(40$ to 95$)$ & $35(3$ to 56$)$ \\
\hline$\geq 65$ & $65(18$ to 85$)$ & $-19(-217$ to 55$)$ & $\mathrm{n}$ too low $^{\mathrm{b}}$ & $-14(-206$ to -57$)$ \\
\hline$\geq 65$ or in a risk group & $46(18$ to 65$)$ & $13(-44$ to 47$)$ & $60(-62$ to 90$)$ & $11(-53$ to 49$)$ \\
\hline \multicolumn{5}{|l|}{ Scheme } \\
\hline RCGP & $46(14$ to 64$)$ & $57(25$ to 75$)$ & $74(15$ to 92$)$ & $50(8$ to 73$)$ \\
\hline SMN & $49(-48$ to 82$)$ & $-22(-246$ to -56$)$ & $\mathrm{n}$ too low $^{\mathrm{b}}$ & $\mathrm{n}$ too low $^{\mathrm{b}}$ \\
\hline HPS & $44(9$ to 66$)$ & $32(-16$ to 60$)$ & $84(-23$ to 98$)$ & $16(-47$ to 52$)$ \\
\hline Public Health Wales & $94(30$ to 99$)$ & $\mathrm{n}$ too $\operatorname{low}^{\mathrm{b}}$ & $\mathrm{n}$ too low ${ }^{\mathrm{b}}$ & $\mathrm{n}$ too low ${ }^{\mathrm{b}}$ \\
\hline PHA of Northern Ireland & 81 (21 to 95$)$ & n too low ${ }^{b}$ & n too low ${ }^{b}$ & n too low ${ }^{b}$ \\
\hline \multicolumn{5}{|l|}{ Time since vaccination } \\
\hline$<3$ months & $57(37$ to 70$)$ & $56(28$ to 73$)$ & $100(66 \text { to } 100)^{c}$ & $50(16$ to 71$)$ \\
\hline$\geq 3$ months & $42(12$ to 61$)$ & $15(-25$ to 42$)$ & $56(-6$ to 82$)$ & $2(-49$ to 36$)$ \\
\hline
\end{tabular}

Cl: confidence interval; HPS: Health Protection Scotland; PHA: Public Health Agency; RCGP: Royal College of General Practitioners' surveillance scheme; SMN: Public Health England Specialist Microbiology Network, VE: vaccine effectiveness.

a Adjusted for age group, sex, month of sample collection and surveillance scheme.

b Number of vaccinated cases/controls too low to give an estimate with meaningful precision (95\% $\mathrm{Cl}$ lower end $<-200$ and upper end >80).

Unadjusted Cornfield $95 \% \mathrm{Cl}$. 
variability across the schemes although this difference was not significant.

Vaccine effectiveness against influenza $B$ infection The adjusted VE of TIV against influenza B was $51 \%$ ( $95 \% \mathrm{Cl}: 34$ to 63 ). VE was $57 \%$ within three months of vaccination and non-significantly lower at $42 \%$ after three months (Table 4 ). VE did not vary by age group or scheme.

\section{Discussion}

In this study we found moderate effectiveness of 2012/13 TIV against laboratory-confirmed influenza B and good protection against influenza $A\left(\mathrm{H}_{1} \mathrm{~N}_{1}\right)$ pdmog infection. However, VE against influenza $A\left(\mathrm{H}_{3} \mathrm{~N}_{2}\right)$ infection was poor at only $26 \%(95 \% \mathrm{Cl}:-4$ to 48$)$. We also found a non-significant trend that effectiveness waned by time since vaccination for influenza $\mathrm{A}\left(\mathrm{H}_{3} \mathrm{~N}_{2}\right)$, which is consistent with the waning seen against influenza $\mathrm{A}\left(\mathrm{H}_{3} \mathrm{~N}_{2}\right)$ for the $2011 / 12$ TIV vaccine in the previous season where it reduced from $53 \%(95 \% \mathrm{Cl}$ : o to 78$)$ within three months of vaccination to $12 \%$ (95\% Cl: -31 to 41) after three months [2]. The point estimate for $2011 / 12$ was also similar for influenza $\mathrm{A}\left(\mathrm{H}_{3} \mathrm{~N}_{2}\right)$ at $23 \%$ (95\% Cl: -10 to 47), although VE was higher in 2011/12 against influenza $\mathrm{B}$ at $92 \%$ (95\% Cl: 38 to 99) compared to $2012 / 13$. The VE against $A\left(\mathrm{H}_{1} \mathrm{~N}_{1}\right)$ pdmog is consistent with that seen with monovalent pandemic vaccine (adjuvanted) in 2009/10 and with TIV in 2010/11 [6,7].

Influenza vaccine strains are propagated in eggs during the vaccine manufacturing process. It has been reported that propagation of the $A /$ Victoria/361/2011(H3N2)-like vaccine viruses for vaccine production resulted in antigenic changes in the virus resulting from adaptation to the growth in eggs, although circulating viruses were closely related antigenically to the cell-propagated influenza $A\left(\mathrm{H}_{3} \mathrm{~N}_{2}\right)$ vaccine strain, $A /$ Victoria/361/2011 [13]. Following these observations the influenza $A\left(H_{3} N_{2}\right)$ vaccine component for use in the $2013 / 14$ season (northern hemisphere winter) has been updated to recommend an influenza $\mathrm{A}\left(\mathrm{H}_{3} \mathrm{~N}_{2}\right)$ virus antigenically like the cell-propagated A/Victoria/361/2011 prototype strain (such as A/Texas/50/2012) [13]. The majority of influenza B virus isolates in 2012/13 were characterised as belonging to the $\mathrm{B} /$ Yamagata/16/88-lineage, as does the $2012 / 13$ influenza $B$ vaccine strain, $B /$ Wisconsin/1/2010. However, genetically, the HA genes of the majority of B-Yamagata strains fell within a genetic clade (clade 2), which in $\mathrm{HI}$ assays are antigenically distinguishable from B/Wisconsin/1/2010 (genetic clade 3)-like viruses. This provides an explanation for the lower VE observed against influenza B in 2012/13 compared to $2011 / 12$. Consequently the influenza $B$ vaccine component recommended for use in 2013/14 has also been updated, to a B/Massachusetts/2/2012 (clade2)-like virus [13].

When stratifying VE by age and scheme, VE is estimated with lower precision. There were no significant differences in VE by age or scheme although the point estimate for VE against influenza A was negative for the SMN scheme and also for the over 65 years age group. These differences are likely to be chance fluctuations due to small numbers and emphasise the need for large numbers of swabs for precise estimates for such subgroup analyses.

This is now the fourth season in which a pooled UK VE analysis has been performed using the TNCC design with mid-season estimates also produced for 2009/10, $2010 / 11$ and 2012/13 [2,3,6,7,14]. Results from the RCGP scheme have also been published for 2005/06, 2006/07 and 2007/08 [15]. The results of each season have been consistent with those published from other countries and from pooled European analyses but often with greater precision in the UK due to the large numbers of swabs. The mid-season $2012 / 13$ results gave VE against influenza A of $49 \%$ ( $95 \% \mathrm{Cl}:-2$ to 75$)$ and influenza B of $52 \%$ ( $95 \% \mathrm{Cl}: 23$ to 70 ), which was similar to other early season results from Europe and Canada $[4,5]$, and also similar to the end of season result of $51 \%$ (95\% Cl: 34 to 63 ) for influenza $\mathrm{B}$, but higher than the end of season result of $35 \%(95 \% \mathrm{Cl}: 11$ to 53$)$ for influenza A. The TNCC design is now the most commonly used method for estimating the VE of influenza vaccines. This reflects the advantages of the method in terms of its simplicity and the fact that those that test negative form an excellent control group as they are well matched on propensity to consult a GP. Further discussion of the methodological issues have been published previously $[12,16,17]$ and a recent paper has demonstrated the methods validity compared to placebo controlled clinical trial results [18].

The intra-seasonal waning of VE against influenza $A\left(H_{3} N_{2}\right)$ seen in 2011/12 in the UK is supported by the estimates seen this year, albeit non-significant. Carehome outbreaks late in the season both in 2011/12 and $2012 / 13$ also support this observation $[1,19]$, as did similar findings in other countries in 2011/12 [20]. With a new influenza $A\left(\mathrm{H}_{3} \mathrm{~N}_{2}\right)$ and $B$ strain recommended for $2013 / 14$ and with the introduction of a trivalent live attenuated intranasal vaccine for all children aged 2-3 years and up to 10 years of age in parts of the UK [21] monitoring of VE remains an essential part of influenza surveillance.

\section{Acknowledgements}

We are grateful to the many primary care physicians in England, Wales, Northern Ireland and Scotland who supplied the clinical information on their patients; to the staff of the PHE Respiratory Virus Unit, the PHE Specialist Microbiology laboratories, Public Health Wales Specialist Virology Centre, the West of Scotland Specialist Virology Centre and the Regional Virus Laboratory, Belfast who undertook analysis of specimens. We thank the staff of the PHE, RCGP, Public Health Wales, Public Health Agency Northern Ireland and Health Protection Scotland teams who coordinate the GP schemes, in particular Joy Field from PHE; Richard Lewis and Hannah Evans from PHW; Catherine Frew, Alasdair MacLean \& Celia Aitken from WoSSVC and Arlene Reynolds, Louise Primrose-Shaw and Karen Voy from HPS for overseeing data 
collection. Funding: The infrastructure and methodology to enable the work was developed as part of a European Centre for Disease Control and Prevention (ECDC) funded project "I-MOVE". The I-MOVE group continues to be co-ordinated by Epi-Concept (http://www.epiconcept.fr/).

We acknowledge the originating and submitting laboratories of the sequences from GISAID's EpiFlu Database on which some of the analyses are based (see Table 1). All submitters of data may be contacted directly via the GISAID website www.gisaid.org.

\section{Conflict of interest}

D Fleming has received consultancy fees from influenza vaccine manufacturers (GSK, Sanofi and Medimmune). The Virus Reference Department of Public Health England receives funding from vaccine manufacturers (CSL, GSK, Novartis and Sanofi, Baxter).

\section{Authors' contributions}

Nick Andrews led the writing of the paper. All authors provided contribution to the paper and approved the final version. Nick Andrews and Chris Robertson performed statistical analyses of the 2012/13 influenza data. Joanna Ellis and Angie Lackenby did strain characterisation on RCGP data and Rory Gunson on Health Protection Scotland data. Richard Pebody, Nick Andrews, Douglas Fleming, Jim McMenamin and Chris Robertson were involved in the original methodological design but all other authors have had a role in modification of this design over the years.

\section{References}

1. Public Health England (PHE). Surveillance of influenza and other respiratory viruses, including novel respiratory viruses, in the United Kingdom: Winter 2012/13. London: PHE; Jun 2013. Available from http://www.hpa.org.uk/Publications/ InfectiousDiseases/Influenza/1306influseasonalannualreport/

2. Pebody R, Andrews N, McMenamin J, Durnall H, Ellis J, Thompson $\mathrm{Cl}$, et al. Vaccine effectiveness of 2011/12 trivalent seasonal influenza vaccine in preventing laboratoryconfirmed influenza in primary care in the United Kingdom: evidence of waning intra-seasonal protection. Euro Surveill. 2013;18(5): $\mathrm{pii}=2038$ 9.

3. McMenamin J, Andrews N, Robertson C, Fleming D, Durnall $H$, von Wissmann B, et al. Effectiveness of seasonal 2012/13 vaccine in preventing laboratory-confirmed influenza infection in primary care in the United Kingdom: mid-season analysis 2012/13. Euro Surveill. 2013;18(5):pii=20393.

4. Valenciano M, Kissling E; I-MOVE Case-Control Study Team. Early estimates of seasonal influenza vaccine effectiveness in Europe: results from the I-MOVE multicentre case-control study, 2012/13. Euro Surveill. 2013;18(7): pii=20400.

5. Skowronski DM, Janjua NZ, De Serres G, Dickinson JA, Winter AL, Mahmud SM, et al. Interim estimates of influenza vaccine effectiveness in 2012/13 from Canada's sentinel surveillance network, January 2013. Euro Surveill. 2013;18(5):pii= 20394.

6. Pebody RG, Andrews N, Fleming DM, McMenamin J, Cottrell S, Smyth B, et al. Age-specific vaccine effectiveness of seasonal $2010 / 2011$ and pandemic influenza $A\left(\mathrm{H}_{1} \mathrm{~N}_{1}\right) 2009$ vaccines in preventing influenza in the United Kingdom. Epidemiol Infect. 2013;141(3):620-30. http://dx.doi.org/10.1017/ So950268812001148

7. Hardelid P, Fleming DM, McMenamin J, Andrews NJ, Robertson C, Sebastianpillai P, et al. Effectiveness of pandemic and seasonal influenza vaccine in preventing pandemic influenza $A\left(\mathrm{H}_{1} \mathrm{~N}_{1}\right)_{2009}$ infection in England and Scotland 2009-2010. Euro Surveill. 2011;16(2):pii=19763.

8. Ellis J, Iturriza M, Allen R, Bermingham A, Brown K, Gray J, et al. Evaluation of four real-time PCR assays for detection of influenza $A\left(\mathrm{H}_{1} \mathrm{~N}_{1}\right)$ v viruses. Euro Surveill. 2009;14(22): $\mathrm{pii}=19230$.

9. Gunson R, Maclean A, Davies E, Bennett S, Miller R, Carman WF. Development of a multiplex real-time RT-PCR that allows universal detection of influenza $A$ viruses and simultaneous typing of influenza $\mathrm{A} / \mathrm{H}_{1} \mathrm{~N}_{1} / 2009$ virus. J Virol Methods. 2010;163(2):258-61. http://dx.doi.org/10.1016/j. jviromet.2009.10.006

10. Matrosovich M, Matrosovich T, Carr J, Roberts NA, Klenk HD. Overexpression of the alpha-2,6-sialyltransferase in MDCK cells increases influenza virus sensitivity to neuraminidase inhibitors. J Virol. 2003;77(15):8418-25. http://dx.doi. org/10.1128/JVI.77.15.8418-8425.2003

11. Zambon M. Laboratory Diagnosis of Influenza. In: Nicholson K, Hay A, Webster RG, editors. Textbook of Influenza. Oxford: Blackwell Science; 1998. pp. 291-313.

12. Orenstein EW, De Serres G, Haber MJ, Shay DK, Bridges CB, Gargiullo $P$, et al. Methodologic issues regarding the use of three observational study designs to assess influenza vaccine effectiveness. Int J Epidemiol. 2007;36(3):623-31. http:// dx.doi.org/10.1093/ije/dymo21

13. World Health Organization (WHO). Recommended composition of influenza virus vaccines for use in the 2013-2014 northern hemisphere influenza season. Geneva: WHO; 21 Feb 2013. Available from: http://www.who.int/influenza/vaccines/virus/ recommendations/

14. Pebody R, Hardelid P, Fleming D, McMenamin J, Andrews N, Robertson C, et al. Effectiveness of seasonal 2010/11 and pandemic influenza $A\left(\mathrm{H}_{1} \mathrm{~N}_{1}\right) 2009$ vaccines in preventing influenza infection in the United Kingdom: mid-season analysis 2010/11. Euro Surveill. 2011;16(6): pii=19791.

15. Fleming DM, Andrews NJ, Ellis JS, Bermingham A, Sebastianpillai $P$, Elliot AJ, et al. Estimating influenza vaccine effectiveness using routinely collected laboratory data. J Epidemiology Community Health. 2010;64(12), 1062-7. http:// dx.doi.org/10.1136/jech.2009.093450

16. Ferdinands JM, Belongia EA, Nwasike C, Shay DK. Influenza vaccination status is not associated with influenza testing among children: Implications for observational studies of vaccine effectiveness. Vaccine. 2011;29(10):1935-40. http:// dx.doi.org/10.1016/j.vaccine.2010.12.098

17. Valenciano M, Kissling E, Ciancio BC, Moren A. Study designs for timely estimation of influenza vaccine effectiveness using European sentinel practitioner networks. Vaccine. 2010;28(46):7381-8. http://dx.doi.org/10.1016/j. vaccine.2010.09.010

18. De Serres G, Skowronski D, Wu XW, Ambrose CS. The test-negative design: validity, accuracy and precision of vaccine efficacy estimates compared to the gold standard of randomised placebo-controlled clinical trials. Euro Surveill. 2013;18(37): pii=20585.

19. Health Protection Agency (HPA). Surveillance of influenza and other respiratory pathogens in the UK, 2011/12. London: HPA; Jun 2012. Available from: http://www.hpa.org.uk/Publications/ InfectiousDiseases/Influenza/1206influannualreport/

20. Kissling E, Valenciano M, Larrauri A, Oroszi B, Cohen JM, Nunes $B$, et al. Low and decreasing vaccine effectiveness against influenza $A\left(\mathrm{H}_{3}\right)$ in $2011 / 12$ among vaccination target groups in Europe: results from the I-MOVE multicentre casecontrol study. Euro Surveill. 2013;18(5): pii=20390.

21. Hakin B, Coford P, Harvey F. Children's flu immunisation programme 2013-14. London: Department of Health and Publich Health England; 26 July 2013. Available from https://www.gov.uk/government/uploads/system/uploads/ attachment_data/file/225360/Children_s_flu_letter_2013.pd 